\title{
The Disabled and Elderly People in Prerevolutionary and Early Soviet Society: Formation of Disability Model in 1900-1938
}

\author{
Alexander S. Kovalev* \\ Siberian Federal University \\ Krasnoyarsk, Russian Federation \\ Krasnoyarsk State Pedagogical University named after V.P. Astafiev \\ Krasnoyarsk, Russian Federation
}

Received 19.11.2020, received in revised form 01.12.2020, accepted 18.07.2021

\begin{abstract}
The first half of the XX century was the time when the model of disability, the main feature of which was the inability to work, was being formed in Russia. Basing on unknown documents from Siberian archives, this article analyses the transformation of the social status of disabled and elderly people in the pre-revolutionary period and the first decades of the Soviet rule. In the Imperial Russia disability was equal to senility. Any person who was no longer able to work, regardless of age, became elderly. In Soviet Russia the hierarchy of disability developed in accordance with the proletarian ideology. The group of disabled workers who had pensions was the most privileged; they were followed by the groups of disabled veterans, who were rehabilitated by health and labor methods, and homeless people with intellectual disabilities, the deaf, the blind, the elderly disabled, and the senile disabled. The latter group was isolated in homes for the disabled. The general direction of the social policy for all categories of disabled people was employment opportunities in compliance with the principle of «utilization of remaining work». The need in the labor force in the period of industrialization led to the emergence of the phenomenon of «working pensioner». As a result, in Soviet Russia a rationally employing model of disability, which was characterized by disability as the inability to work without the inclusion of other characteristics, was formed. The majority of the disabled were elderly people who were not involved in any type of rehabilitation. State social policy in respect of the disabled focused on their involvement in the labor force, which contributed to their integration into society.
\end{abstract}

Keywords: the disabled, the elderly, models of disability, working pensioner phenomenon, pension, homes for the disabled, employment of persons with disabilities, utilization of labor.

Research area: history and archaeology.

\footnotetext{
(C) Siberian Federal University. All rights reserved

* Corresponding author E-mail address: askovaleo@gmail.com ORCID: 0000-0002-5372-8930
} 
Citation: Kovalev, A. S. (2021). The disabled and elderly people in prerevolutionary and early soviet society: formation of disability model in 1900-1938. J. Sib. Fed. Univ. Humanit. soc. sci., 14(8), 1239-1250. DOI: $10.17516 / 1997-1370-0800$.

\title{
Инвалиды и пожилые люди в дореволюционном и раннем советском обществе: формирование модели инвалидности в 1900-1938 гг.
}

\author{
А.С. Ковалев \\ Сибирский федеральныий университет \\ Российская Федерация, Красноярск \\ Красноярский государственный педагогический университет им. В. П. Астафьева \\ Российская Федерачия, Красноярск
}

\begin{abstract}
Аннотация. В первой половине XX века в России происходит оформление модели инвалидности, основной характеристикой которой была нетрудоспособность. Основываясь на неизвестных документах сибирских архивов, автор рассматривает трансформацию социального статуса инвалидов и пожилых людей в дореволюционный период и первые десятилетия советской власти. В имперской России инвалидность приравнивалась к старости. Престарелым становился любой человек, кто больше не мог трудиться, независимо от возраста. В большевистской России в соответствии с пролетарской идеологией сложилась иерархия инвалидности. Наиболее привилегированной была группа инвалидов труда, которые пользовались пенсионным обеспечением, далее следовала группа инвалидов войны, которых реабилитировали медицинскими и трудовыми методами, и «беспризорные» инвалиды - с интеллектуальными нарушениями, глухонемые, незрячие, а также пожилые инвалиды, или инвалиды старости. Последнюю группу изолировали в инвалидные дома. Общим направлением социальной политики для всех категорий инвалидов было возможное трудоустройство в соответствии с принципом «утилизации оставшегося труда». Потребность в трудовых ресурсах в период индустриализации привела к появлению феномена «работающего пенсионера». В результате в Советской России сформировалась рационально-трудовая модель, для которой было характерно понимание инвалидности как неспособности к труду без включения других характеристик. Основную массу инвалидов составляли пожилые люди, которые не были вовлечены ни в один из видов реабилитации. Государственная социальная политика в отношении нетрудоспособных была ориентирована на вовлечение инвалидов в трудовые процессы, что способствовало их интеграции в общество.
\end{abstract}

Ключевые слова: инвалиды, пожилые люди, модели инвалидности, феномен работающего пенсионера, пенсия, дома для инвалидов, трудоустройство инвалидов, утилизация труда.

Научная специальность: 07.00. 00 - исторические науки и археология 


\section{Introduction}

The ongoing policy towards disabled people implemented by the Russian state is often a source of criticism. In the scientific literature it is often defined as ineffective, unable to overcome many social barriers (Dement'eva, Kholostova, 2005; Romanov, Iarskaia-Smirnova, 2006). One of the reasons for the ineffectiveness of modern social policy is its orientation to historical traditions, which contributed to the establishment of the model of disability limiting the independence of the population that was unable to work (Romanov, Iarskaia-Smirnova, 2006; Shek, 2005). Among these traditions is that of the desire to treat persons with disabilities as a social minority with special status which does not allow them to fully function in society. However, until now there have been no specific studies devoted to identifying the kind of model of disability that was ultimately formed in the Soviet Union.

In some works of foreign authors we can find the information about the evolution of attitude towards persons with disabilities, about the opposition of the medical and social models of disability. According to the first model, persons with disabilities are not capable to carry out anything that is characteristic for the average person, so we need to help them by creating special facilities where they could work on the accessible level, communicate, and receive a variety of services. The second model suggests that the difficulties for the disabled should be created by society that does not imply their participation in social activities. It calls for the creation of accessible environment for the disabled, as well as the implementation of the measures that promote social and vocational rehabilitation (Hubert, 2000; Pearson, 2005).

In this regard, a person's life practice shall be in the spotlight. Therefore, American historians P. Longmore and L. Umansky propose to consider the elimination of disability to be beyond the medical field and the approval of a full-fledged social status of persons with disabilities to be the index of social policy's effectiveness (Longmore, Umansky, 2001).

Russian researchers of the history of disability keep to the point of view that, until 1990-ies the disability policy in Russia had been implemented only in accordance with the first model that was traditional. Nikolay Malofeev wrote fragmentarily about the attitude to persons with disabilities in Europe and Russia in the context of the emergence of Special Education. His studies show that the leading role in the organization of Special Education belonged to medical concepts (Malofeev, 2009; 2013).

At the same time, Sarah D. Phillips writes that the Soviet government adhered to «functional» model of disability, based on the perception of a person through the prism of «helpfulness for society». After the establishment of the Soviet state the term «disabled person»" came to mean the Soviet citizens who had lost their ability to work. Understanding of disability as a loss of labor potential was a cornerstone of the disability policy in the proletarian Soviet Union, where all citizens had to participate in socially useful activity. A citizen's social helpfulness was measured only by one potential role in production, and the level of disability was assessed on the scale of «labor capacity» (Phillips, 2009).

\section{Social status of disabled and elderly people to revolution}

Speaking about the formation of the Soviet model of disability in Russia, we should, first of all, pay attention to the status of persons with disabilities in the context of the urbanization process, which lasted until the middle of the XX century. The formation of the status of a disabled or elderly person was seriously affected by the ideology of the state social policy and its practical implementation. It determined the status of the disabled through the mechanisms of distribution of social benefits and the amount of guarantees. In this case, there were certain problems in the society's determination of clear boundaries between different groups of disabled people, between persons with disabilities and the elderly.

There were no such concepts as «old age» or «elderly» in Russia either before the revolution or after it. Explanatory Dictionary of the Living Great Russian Language by Vladimir Dal' defines the phrase «to grow old» ("prestaret'» - in the Russian dictionary) as «to get senile» and the word «elderly» as «liv- 
ing out one's remaining days», "people under 60 and more» (Dal', 1865a: 1108; Dal', 1865b: 202-203, 300; Da', 1866: 288). It means that in the pre-revolutionary period in Russia old age was understood as a human life cycle, which was characterized by blurring boundaries of age and senility in understanding of the failure to act independently and «living the last years as the life is». For example, Mikhaill Kazadaev from Tomsk, who was a participant of the Crimean War and a retired soldier, was not considered an old man as he was able to work till the age of 93. Only at this age he turned to Tomsk City Government to apply for a grant of benefit ${ }^{1}$.

Yet, Krasnoyarsk Civil almshouse was home for «the elderly women - a 54-year-old Agrafena Parfenova and a 65-year-old Aleksandra Cherdakova ... due to their age and weakness» and «senility»; they were unable to work and «could not get food», felt «weak», «senile», and «ignorant of body, arms and legs» ${ }^{2}$.

If an old man was diagnosed to have «blindness», «paralysis» or "weakness of strength», then he did not get the status of «disabled» because of this. This status seemed not to exist at all. The archival materials lack the words «poor», «ailing» or «sick». The word «disabled» is used only as a synonym for the word «veteran», and in poorhouses we find people who are obviously far from the old age - they are 30,40 or 50 years old. In all reports or statistical data only a physical ailment of the residents of poorhouses, such as «feeble-minded», «lame», «deaf», «blind», is mentioned. Even among the veterans the phrase «disabled veteran» is rarely mentioned, the word «pensioner» is occasionally met, but this designation could refer to anyone who got a pension (because of the old age, injury, superannuation, service), even to a single mother. Therefore, speaking of the early XX century, we should be careful about identifying an elderly person with a retired one: people could «retire» in a relatively mature, but not old age of 52-55, be healthy, have a family, keep a house, and the designations «old» and especially «elderly» are hardly appropriate for such people.

SATR. F. 233. OP. 2. D. 3407. L. 48.

SAKR. F. 518. OP. 1. D. 11. L. 2-3.
Thus, coalescence of both groups happened. Elderly and disabled people were united by a common status of "unable to work» because of their physical illness or age. They were also united by the concept «aged», since ordinary people regarded a person who was not old by age but incapable to work because of a disease as the one who was already «living» one's remaining days that meant he was aged.

The term «person with disabilities» firmly embedded in the lexicon of Russian society only during World War I, when on the background of the patriotic wave those who were injured in the lines («war invalids») were included in a special category. However, their status was still perceived through the prism of efficiency. Now they were paid a pension (benefit) according to the degree of loss of efficiency, but were still considered to be able to work. For the first time the attitude to a disabled person was shown from the perspective of their «helpfulness» for society and the desire to «squeeze» the remaining amount of efficiency out of them. At the same time, those were the first attempts to create a mechanism of professional and labor rehabilitation of persons with disabilities, arranging training and employment of «injured soldiers» (apprenticeship, courses for future priests, agricultural education $)^{3}$. It was not profitable for the state to maintain disabled veterans, who were still able to work, and it tried to differentiate them. Some were still in the combined group of «unable to work» and others were withdrawn from the group with the change in the status - from «injured soldier» into «socially active citizen|».

\section{The disabled and the elderly in the early Soviet period: differentiated approach to disability}

During the Revolution and the Civil War, the status of the disabled and the elderly was not significantly changed. However, when the Soviet government won and the socialist idea of social security replaced the bourgeois ideology of public charity, the position of the contingent in question changed.

At first, the new social policy in regard to persons with disabilities and the elderly was

SATR. F. 170. OP. 4. D. 522. L. 1. 
not very different from the pre-revolutionary one. The living conditions in homes for the disabled, which replaced poorhouses, remained the same. Many «non-Soviet» elements (one White Army soldier from Tomsk even got retirement benefit and worked in the labor crew on a par with the disabled of the Red Army) were amnestied, pre-revolutionary pensioners were equalized in their rights. On the one hand, it was an attempt to form an unbiased approach to persons with disabilities. On the other hand, it continued the pre-revolutionary tradition, according to which those who could work had to contribute to society till the very old age.

In December 1921, the Decree of People's Commissars «On Social Security of Disabled People» introduced the 6-group classification of disability:

1) a disabled person who is not capable of professional work and in need of outside help;

2) a person who cannot perform professional work, but is able to dispense with outside care;

3) a person who is unable to work regularly, but able to earn their living through casual, easy work;

4) a disabled person who is able to change a job for a new one that requires lower qualifications;

5) a disabled person who is obliged to find a new job of the same qualification;

6) a disabled person who may continue their professional work with the lowered productivity (Dekret..., 1921).

S.D. Phillips mistakenly believes that in 1920-30-ies these two main groups - the elderly and disabled veterans - made the majority of persons with disabilities (Phillips, 2009). In fact, during this period a complex hierarchy formed among the disabled population. Under the influence of the ideology the principal place in society was occupied by a «working man» who received the right to belong to a privileged part of society. Gradually the unbiased approach transformed into the differentiated and class approach. Disabled workers were separated from all persons with disabilities in a special group. Then, there were two more separated groups in the «hierarchy of the disabled» - the disabled of the Red Army and the disabled of «the imperialist war». In reality entirely different division occurred instead of a formalized legal classification. At the same time, the elderly «disappeared», the Soviet documents mention only «the senile disabled», but the other name is more common - «homeless persons with disabilities» («besprizornye invalidy» - in Russian $)^{4}$. Thus, in the first decade of Soviet power there was a merger of the two categories - the elderly and the disabled, whereas the words «old» and «elderly» disappeared and the term «disabled» brought together all those who could not work. As a result, it turned out that the status of a disabled person had a large impact on the set of rights and privileges which a person could use. If «the military» and «working people» in accordance with the ideology of the state regarding workers and peasants were favoured by the state to some extent, the others (who did not have the necessary proletarian characteristics) were left out of social security in Soviet Russia. The same applied to elderly people - if an old man could prove that he had fought against Germans or participated in the Civil War «against the counter-revolution», or had the proletarian experience, then he automatically fell into the category of «privileged» persons with disabilities who could claim pension, benefit or placement in a home for the disabled. Otherwise, an old man found him/ herself in the position of his/her predecessor in pre-revolutionary Russia, who was not regarded as a city's pensioner and was not allowed to stay in a poorhouse due to caste prejudices or the absence of other bases for charity. In fact, in both cases an elderly man did not have so many options of further existence - he/she could pull $\mathrm{him} /$ herself up and continue to work, or make his/her living through begging.

For example, an old man from Tomsk Yakov Yakovlev did not participate in the war, he had been a lawyer before the revolution, but this activity was not admitted as «proletarian». The old man's good health made it impossible to put him to a home for the disabled as a senile disabled one. Therefore, in 1921 at the age of 70 Yakovlev was forced to re-apply for a job and do manual labor to get the required 8-yearold proletarian experience, become a disabled

\footnotetext{
4 SAIR. F. R-558. OP. 1. D. 60. L. 41, 42, 120.
} 
worker and get a pension. Here is what he wrote about himself in a statement to the insurance cash: «For two years I worked as a repair worker at the Siberian railway, at the construction sites of telephone networks, developed backyards, greenhouses and hotbeds, participated in the census, worked as a gardener $)^{5}$. Only in 1929 Yakovlev was recognized to be a disabled worker of group 2 and was to get a pension. So, for many people age was still of a minor importance.

Thus, the Soviet state first proclaimed and legislatively established its responsibility before the disabled and elderly, but followed the class approach, which eventually converted into the discriminatory one, and the barriers which excluded persons with disabilities out of society began to form.

Even in homes for the disabled «homeless» old people, disabled workers and war veterans conflicted with each other. By the mid 20 -ies the Soviet power started to provide persons with disabilities with a place in a home for the disabled, but there, the elderly experienced an unfair attitude again. Here are some of the most revealing examples from the reports on the organization of services in Siberian homes for the disabled ${ }^{6}$ :

The homeless persons with disabilities, who are mostly elderly ... are given worn linen. They are hurt by not receiving clear linen, clothing, and bedclothes. Instead, they receive torn and tattered clothes. Besides, the allowance for them is issued half as little as for the disabled workers and veterans, and of worse quality.

The old people have not had a shower for a month ... receive poor nutrition ... The wards of the homeless are dark; care and cleaning are bad.

Meals for the persons with disabilities are cooked in fewer amounts than those for the disabled workers or veterans which are cooked in different boilers.

\footnotetext{
SATR. F. R-446. OP. 1. D. 70. L. 25, 27.

6 SAIR. F. R-558. OP. 1. D. 60. L. 41-45, 120-120ob;

F. R-558. OP. 1. D. 90. L. 9-9ob, 32.
}

Allowance is given to the disabled in two different ways ... The homeless get allowance in less amount: less meat, a quarter of a standard amount of bread without wheat-bread, half of cereals, fats, sugar, and tea ... The food is cooked by two cookers, i. e. one of them cooks for the homeless, and the other one does for the disabled workers and veterans.

All the homeless are in dirty rags. Among this mud is always a disabled worker or veteran, who has a mattress, trousers, underwear and a good allowance.

There is a pile of old rags with awful smell and countless lice under the mattresses of the homeless which the disabled workers do not have. But the newcomers bring insects which anyway enter any corner no matter how hard you try to protect from them ... The elderly homeless people are in torn clothes, dirty, angry. Nearly 40 homeless persons with disabilities, many of whom are old, are in a very difficult situation. The old people are left to the mercy of fate. There is no control, the kitchen is broken down, they are housed in different rooms of the vast building, shitting everywhere and pouring slops at random ... The room is not cleaned, latrines are overfilled and not cleaned, the yard is in a mess of slop. No shower is provided.

The situation of homeless elderly persons with disabilities in society was unenviable, but there was another group among persons with disabilities whose rights were still more limited compared to those of the homeless. Another category was blind, deaf and mentally retarded persons with disabilities. They did not fit into the Soviet ideology of workers' social security, because most of them were those who had not participated in the war, did not work because of their illnesses, and, therefore, they did not have the right for being supported by the new system of social assistance. Only those, who had had work experience preceding the disability of sight or hearing, were included into the «privi- 
leged caste» of disabled workers and got all the rights for social security.

As for people with sight disability, in the article «Slepye v RSFSR» («The blind in the USSR»), in which the blind were accused of the fact that they did not have any labor service obligations, cost society and the state too much and did not want to do hard labor, B.P. Sobkovich mentioned that «the blind are another mouth, nuisance, useless being, requiring care and spending» (Sobkovich, 1922: 3).

Olga Zhukova from Irkutsk, who was blind from the birth, wrote in 1927:

I, as a blind person not capable of any work, could not work or serve either before or after the revolution. Before the revolution, I, as a disabled person, had got a pension, but the Soviet government refused to continue that because of the absence of work experience, which I certainly could not have due to the above stated reasons ${ }^{7}$.

From 1921 to 1927 Zhukova was without any means of support, had to beg, and only 6 years later she was testified by a medical commission and acquired the disability status of group 2.

\section{The Soviet social policy for the disabled and the elderly: \\ social security and «utilization of labor»}

Returning to the question concerning which model of disability developed in Soviet Russia in the 20-ies and 30-ies, we should mention that in the medical model all social problems associated with disability were described in terms of the functional characteristics of a human body. The medical model is closely related to the functional model, which, according to Phillips, describes the disability as a failure (limited ability) of people to perform certain functions equally to healthy people. In particular, in the USSR the functional limitation of the disabled manifested in the absence of working ability and, as a consequence, economic selfsufficiency (Tarasenko, 2004).

The medical and functional models are closely related to the rehabilitation model. The rehabilitation model of disability is typical for the organization of social assistance to disabled veterans who needed medical treatment, psychological therapy to integrate into society and the special government measures to enter the labor market, including job quotas for the disabled at enterprises (Saxton, Kaplan, 1999). Consequently, the Soviet model of disability was to promote rehabilitation of persons with disabilities who were recognized disabled as well as rehabilitation of functional organism disorders which led to a loss of working efficiency. The Soviet state's social policy was aimed at realizing this task. It included:

- pension provision of the disabled;

- medical care;

- social security in homes for the disabled;

- employment of persons with disabilities in accordance with the principle of «utilization of labor»!.

The right for a pension and place in a home for the disabled was given only to the disabled of groups 1-3. Those who were assigned to groups 4-6 had the right for unemployment benefits and a priority right for employment through the employment office ${ }^{8}$. However, as Phillips rightly said, pensions were intended to compensate for lost wages, but not incurred physical or mental damage, and were calculated on the basis of disability group, disability causes, work experience preceding the onset of disability and income (Phillips, 2009).

The medical service for disabled and elderly people in the earliest Soviet period was characterized by both positive and negative trends. The primary diagnosis of health of the disabled and the medical expertise were at a high level. The functional responsibilities of the medical staff were identified, the problems of providing the disabled with drugs were solved, and the procedure for maintenance of patients with disabilities and the elderly was established. The quality of primary health care was at an extremely low level, the failure to render aid often led to death. The management of homes for the disabled faced with interagency barriers and lack of understanding on the part of health professionals when they accompanied persons

\footnotetext{
8 SAKR. F. R-270. OP. 1. D. 2. L.14.
} 
with disabilities for examination and treatment in health care institutions.

When it came to placing a disabled person to home for the disabled, it was not about the social care, but it was only about the necessity to eliminate the social problems left in the socialist state after «the tsarist regime», isolating the elderly and the disabled as the bearers of «begging and homelessness» in a closed institution. Therefore, the Soviet government believed that it was sufficient to provide the disabled with a bunk, food, and clothing.

Organization of leisure-time activities in homes for the disabled was considered unnecessary, "carrying out the cultural and educational work was considered irrational»?. Working activity in homes for the disabled was limited to self-service. Involvement in work was expressed by the following ideological attitude: «All healthy persons with disabilities who are able to move without outside aid or crutches should work as they are able and should not give up without a good reason». However, people with disabilities stated that «no one can force us to work» and that even if they had wanted they would not have started any work. Therefore, social security services recommended the managers of homes for the disabled to persuade persons with disabilities rather than force them to work: «No one has the right to force a disabled person to work $\rangle^{10}$.

However, many persons with disabilities, despite their age and health state, really worked hard. Some of them sold raffle tickets; others did unskilled work at small-scale enterprises. The works in homes for the disabled were rather simple: refuse collection, construction of toilets, cleaning the yard, chopping wood, etc. Persons with disabilities received additional allowance for participation in the working activities and self-service ${ }^{11}$.

The involvement of the disabled occupants of homes for the disabled in work was notable for its extreme inconsistency. First of all, the self-service of the disabled actually merged with public works and their daily work together

\footnotetext{
9 SAKR. F. R-270. OP. 1. D. 44. L. 22ob.

10 SATR. F. R-198. OP. 1. D. 8. L. 34-34ob.

11 SAIR. F. R-558. OP. 1. D. 60. L. 41ob-42; SATR. F. R-198. OP. 1. D. 8. L. $45-45$ ob.
}

with the work of elderly people in the institutions. Secondly, no assistance except for additional allowance was provided for the disabled workers. Thirdly, labor activity of the inhabitants of homes for the disabled was determined not by ideological attitudes but the desire of the disabled and elderly to remain full citizens even in the conditions of the loss of a large percentage of working efficiency. At the same time the labor of disabled people was not considered as a rehabilitative measure, its «therapeutic» effect was not taken into consideration at all. Therefore, labor activity of the disabled, designed to fill their daily reality with additional sense, in fact remained an ideological postulate of the concept of «utilization of labor».

The Bolsheviks understood the term «utilization of labor» as the use of the benefit of the rest of working efficiency of the disabled: «No person with disabilities, prone to be used as a useful member of the state, should be left without work $\rangle^{12}$. At the same time the Soviet government «warned» and almost immediately labeled: "A disabled person who is not involved in any work becomes a parasite of society $\rangle^{13}$.

According to the decree of the Council of People's Commissars «On Social Security of Persons with disabilities», persons with disabilities of groups 3-6 were designated as able to work, whom the government offered several options of employment.

Firstly, it was work in teaching and support workshops. Sewing, carpentry, linen, weaving and game types of production were offered them as requiring no special professional skills and providing a disabled person with an opportunity to be taught a new craft.

Secondly, it included employment in specially designed disabled persons' artels. Here, those who had had a job before the onset of disability and retained the ability to work even with physical damage could find a job. For example, a shoemaker, who had lost a leg in the war, but could continue to work doing the same job though in a sitting position, could be employed in such an artel. However, a disabled person, who wanted to join this artel, had to

\footnotetext{
${ }^{12}$ SAAR. F. R-18. OP. 3. D. 63. L. 20; SAKR. F. R-270. OP. 1 D. 2. L. 30 .

13 SAKR. F. R-270. OP. 1. D. 2. L. 30.
} 
give up the pension provision. Thus, the state had a very rational approach to the problem of social security - a disabled person could choose either a pension or a chance to earn money. At the same time, artels and workshops were provided with special and relaxed work environment for persons with disabilities.

The feature of both types of employment was that the compulsory condition of their creation was the attraction of the non-disabled, healthy workers. It was an attempt to create one of the first systems of social integration and inclusion of persons with disabilities into society in the history of mankind.

In the 20-ies either backup jobs for the disabled, or measures of social protection of disabled workers, did not appear. The legal protection of persons with disabilities who returned to work should be called weak as they were most of all discriminated by healthy workers even in homes for the disabled. The real ability to work that the disabled had was high enough. This is proved by frequent requests for the provision of employment aid. In the conditions of a small size of pensions and benefits the disabled viewed their own labor as a major source of self-support. But still there were no sufficient material resources to provide the disabled people willing to work with jobs. Employment of the disabled could not go beyond the creation of specialized enterprises - artels. Its further development was possible only in the conditions of the early industrialization.

At this time the actualization of society's labor resources got a special significance. In the conditions of the shortage of workforce the Council of People's Commissars set the regional authorities the task to use all «possibilities of additional attraction of the workforce through the use of the remainder of the ability to work of the disabled $»^{14}$.

The third area of the employment policy concerning the disabled was the use of the disabled persons for easy and low-skilled jobs. In 1930, a new procedure for employment of persons with disabilities was established. A disabled person was recorded in the personnel department at the place of his/her residence

\footnotetext{
${ }^{14}$ SATR. F. R-446. OP. 1. D. 11. L. 88.
}

and then was sent to the Committee of medicalprofessional screening and selection («medprofotbor» - in Russian), which defined «the possibility of the use of the disabled» in relaxed conditions for the same job, for unskilled work, for a new job, as well as for working as instructors. Persons with disabilities, found able to work, were sent for easy work in institutions and enterprises. Healthy employees lost their jobs and were offered another job in the same company or in another company ${ }^{15}$.

That is how the formation of the reservation of jobs for persons with disabilities began. In addition, the People's Commissariat of Labor identified a number of posts which were specially booked for persons with disabilities in enterprises and institutions. The list included seven groups of vacancies in various fields: «service personnel» (couriers, cleaners, porters, etc.), «trade officials» (receptionists, salespeople, etc.), workers in the medical sphere, «railway workers» (stationmasters, porters), «print workers», «textile men», and «food industry workers $»^{16}$.

Such a program could be interesting for the disabled due to the extensive benefits and incentives: free utilities, extended leave, priority prosthetics and giving resort treatment, extra provision of goods, etc. ${ }^{17}$

However, this policy led to the fact that persons with disabilities found themselves up the tree. Having agreed to be employed, they moved from a higher group of disability down to the lower one, received lower pensions, and lost the opportunity to use full social protection. In addition, the ability of persons with disabilities to work led to the fact that sometimes even the disability of an armless or legless person, who «firmly switched to a rather qualified job with sufficient earnings» was denied ${ }^{18}$. It is not surprising that as a result of such a policy in 1932 disability of groups 4-6 was canceled. All those who were considered disabled before were either assigned to group 3 or were no longer treated as disabled at all. So, in this way a paradoxical phenomenon of «a working dis-

\footnotetext{
${ }^{15}$ SATR. F. R-446. OP. 1. D. 11. L. 88ob.

16 SATR. F. R-446. OP. 1. D. 11. L. 89

17 SATR. F. R-446. OP. 1. D. 11. L. 90-104.

18 SARF. F. A-390. OP. 17. D. 145. L. 11-12.
} 
abled person who is not able to work» began to take shape in Soviet society.

Employment of disabled veterans, workers, and «homeless» persons with disabilities went on evenly with a small increase in the number of the latter. Because of the low pensions and high inflation rate eating up insignificant allowances, persons with disabilities were forced to accept any job. For disabled workers job reservation successfully developed at enterprises and institutions. Disabled veterans and persons with disabilities of old age who did not have any work experience, the deaf and the blind were offered low-paid, unpopular jobs. However, every disabled person was given the opportunity to make living by work and to integrate into the labor community ${ }^{19}$.

Besides, the state, involving persons with disabilities into the workforce and actually depriving them of a pension as a deserved source of income, was able to propose not only wages instead, but additional social guarantees as well. There was no payment of the state pension to disabled workers during the whole period of the New Economic Policy, but with the onset of industrialization there was the precedent of paying the pension to the disabled workers and the elderly. The phenomenon of «working pensioner», that would later become a distinctive feature of Soviet social policy and remain in Russia up to date, was being formed along with the phenomenon of «disabled worker». Since April 1932, depending on their qualifications and a particular group of disability, working pensioners were paid $50-75 \%$ of the pension together with wages. Since 1938, working elderly people started receiving pensions in full regardless of their income ${ }^{20}$. From the point of view of the economy double provision was an absolutely wrong decision, but from the perspective of building socialism this stimulation of the «working class» seemed a great achievement both to the Soviet people and the whole world.

Of course, the disabled workers were a kind of «resource for achieving the goals of the state». However, we cannot assume that persons with disabilities during the period of

\footnotetext{
19 SATR. F. R-446. OP. 1. D. 2. L. 12.

${ }^{20}$ SATR. F. R-562. OP. 1. D. 5. L. 63-66.
}

Stalin's modernization were perceived solely as a passive element of the society and economy, requiring maintenance through another part of the population. The working conditions for disabled persons were identified by the current social legislation. Persons with disabilities occupied a special position in the field of employment and labor relations. They were provided with easy work. Material support for working persons with disabilities in the 30 -ies was limited to a partial payment of the pension. At the same time, workers with disabilities and elderly people got a chance to use resort treatment, prosthetics and other services more often.

The policy of employment provided persons with disabilities with independent income, relatively independent life, and at the same time removed from the state the need in ongoing expenses for social assistance. However, the employment policy measures did not include vocational orientation and adaptation of the disabled at the workplace; in the conditions of the formation of totalitarian society legal protection of persons with disabilities did not take any shape. Gradually, work as a means of rehabilitation of the disabled was replaced by the idea of full employment, and the disabled were isolated in homes for the disabled and invalid artels again.

\section{Conclusion}

Thus, from 1900 to 1938 the disabled and the elderly were a single category, which was brought together by a common symptom that was the lack of working efficiency, the inability to make living by their work without relatives and with weak physical health. But we should not forget that even though before the revolution the term "disabled person» was hardly mentioned, and all disabled people were automatically equated to the elderly, after the revolution the situation changed dramatically. The social status of the disabled and the elderly merged into a single one, and in the conditions of the formation of the proletarian ideology of social security for the disabled and the elderly the following principle was actively applied: «those who did not work should not eat». In relation to this approach persons with sight or hearing disabilities who had never worked 
were automatically excluded out of the Soviet social security system. The seniors and elderly people gradually dissolved in the total mass of persons with disabilities and became «senile disabled persons»».

Traditionally, «disabled» means «useless». With regard to the period under the research we talk about a person's ability to work and his/her compliance to the demands of the society, calling for the long-term preservation of working efficiency. The main characteristic feature identifying a disabled person was the inability to perform regular professional work as a source of self-sufficiency. However, such a classification included only elderly people who "were unable to work because of their senility». This fact contributed to the change of the status of an elderly person and also determined a set of social rights they may have had (pensions, social service in homes for the disabled, volunteer assistance, etc.).

Other persons with disabilities faced a paradoxical situation: before falling into the category of the disabled, they had to have gained a certain working experience, and then had to try to return to the economically active population. The status of «disabled person» gave its holder the right to use the pension provision and many benefits, but at the same time excluded such a person from society, as there was no place for the unemployed in a new social structure.

However, in the first post-revolutionary decades the social policy of the Soviet government laid the basis for the state care of persons with disabilities and the elderly. At the same time there was a specific model of disability, which was characterized by the synthesis of elements of medical, functional, rehabilitation and social models. The examination of disability, the elements of rehabilitation as recovery of job skills of disabled and elderly people, the formation of pension provision and the system of institutions of social services were taken from medical and rehabilitation models. At the same time, awareness of disability as not only a personal tragedy but also the loss of the ability to function socially in full attempts to realize social integration and to overcome the social exclusion of the disabled people through their involvement in employment along with healthy people showed the formation of a new social model of disability.

The model of disability, which had been formed in Russia by the beginning of World War II, may be called the rationally employing model with the following features.

First of all, it is the conception of disability understood as the inability to work without the inclusion of other characteristics. Nevertheless, we should agree with Phillips, that the term «disabled» had negative connotations and represented a standard set of certain features: social (a disabled person is excluded), psychological (single, closed), labor (an unskilled worker with limited skills and intelligence), and economic (dependent, retired).

Secondly, the bulk of persons with disabilities were «homeless» persons with disabilities, who were also identified as the senile disabled. The Soviet regime did not need them, since their work could not be utilized. In this regard, the elderly were isolated in homes for the disabled where they were provided with food and clothing, but were not involved in any type of rehabilitation.

Thirdly, the rationality appeared in the paternalistic nature of social policy focused on separation of the employable from the disabled and carrying out activities aimed at labor rehabilitation. In the proletarian state where all those, who did not work, suffered from social exclusion, involvement in the labor processes meant social rehabilitation and integration into society.

Thus, the rationally employing model of disability became the first real model of disability that developed in Russia. It was caused by the fact that the state conducted a targeted policy towards disabled and elderly population for the first time. Besides, it oriented to maximal use of their remaining working efficiency. Unfortunately, the disabled and the elderly were the most vulnerable social group, and the further social policy increasingly tended to isolate persons with disabilities in special institutions. 


\section{References}

Dal', V.I. (1863). Tolkovyi slovar' velikorusskogo zhivogo iazyka [Explanatory Dictionary of the Living Great Russian Language]. Moscow. 627 p.

Dal', V.I. (1865a). Tolkovyi slovar' velikorusskogo zhivogo iazyka [Explanatory Dictionary of the Living Great Russian Language]. Moscow. 1351 p.

Dal', V.I. (1865b). Tolkovyi slovar' velikorusskogo zhivogo iazyka [Explanatory Dictionary of the Living Great Russian Language]. Moscow. 508 p.

Dal', V.I. (1866). Tolkovyi slovar' velikorusskogo zhivogo iazyka [Explanatory Dictionary of the Living Great Russian Language]. Moscow. 680 p.

Dement'eva, N.F., Kholostova, E.I. (2005). Sotsial'naia reabilitatsiia [Social Rehabilitation]. Moscow, Dashkov i Ko, 304 p.

Hubert, J. (2000). Madness, Disability and Social Exclusion; the archaeology and anthropology of «difference». Medical Model Vs Social Model. Routlege, One World Archaeology, 272 p.

Longmore, P.K., Umansky, L. (eds) (2001). The New Disability History: American Perspectives. New York, New York University Press. 416 p.

Malofeev, N.N. (2009). Spetsial'noe obrazovanie v meniaiushchemsia mire. Evropa [Special education in a changing world. Europe]. Moscow, Prosveshchenie, 319 p.

Malofeev, N.N. (2013). Spetsial'noe obrazovanie v meniaiushchemsia mire. Rossiia. [Special education in a changing world. Russia]. Moscow, Prosveshchenie. 320 p.

O sotsial'nom obespechenii invalidov: Dekret Soveta Narodnykh Komissarov [On social security for the disabled: Decree of the Council of People's Commissars] (1921), In Sobranie zakonov RSFSR [Collection of Laws RSFSR], 79, 672.

Pearson, J. (2005). Representing the Lives of Disabled People in History. Colchester: Colchester Museums. 280 p.

Phillips, S.D. (2009). «There Are No Invalids in the USSR!»: A Missing Soviet Chapter in the New Disability History, In Disability Studies Quarterly, 29 (3). Available at: https://dsq-sds.org/article/view/936 DOI: http://dx.doi.org/10.18061/dsq.v29i3.936.

Romanov, P.V, Iarskaia-Smirnova, E.R. (2006). Politika invalidnosti: Sotsial'noe grazhdanstvo invalidov v sovremennoi Rossii [Disability policy: social citizenship of disabled people in Modern Russia]. Saratov, Nauchnaia kniga, 2006. 260 p.

Saxton, M., Kaplan, D. (1999). Disability Community and Identity: Perceptions of Prenatal Screening, In Gene Watch, 12 (2), 4-8.

Shek, O. (2005). Sotsial'noe iskliuchenie invalidov v SSSR [Social exclusion of disabled people in the USSR], In Nuzhda i Poriadok: Istoriia Sotsial'noi Raboty v Rossii, XX v. [Need and order: the history of social work in Russia, the XX century]. Saratov, Tsentr sotsial'noi politiki i gendernykh issledovanii, Nauchnaia kniga, 375-396.

Sobkovich, B.P. (1922). Slepye v RSFSR [Blind in RSFSR], In Izvestiia Narodnogo komissariata sotsial'nogo obespecheniia [News of the People's Commissariat of social security], 43, 3.

Tarasenko, E.A. (2004). Sotsial'naia politika v oblasti invalidnosti: kross-kul'turnyi analiz i poisk optimal'noi kontseptsii dlia Rossii [Disability policy: cross-cultural analysis and optimal conception search for Russia], In Zhurnal issledovanii sotsial'noi politiki [The Journal of Social Policy Studies], 1, 7-28.

\section{List of abbreviations}

SAIR - State archive of Irkutsk region

SAKR - State archive of Krasnoyarsk region

SAIRNH - State archive of Irkutsk region's newest history

SARF - State archive of Russian Federation

SATR - State archive of Tomsk region

SAAR - State archive of Altai region 